\title{
SHAPE ANALYSIS OF CUMULATIVE PROBABILITY DENSITY FUNCTION OF RADIOCARBON DATES SET IN THE STUDY OF CLIMATE CHANGE IN THE LATE GLACIAL AND HOLOCENE
}

\author{
Danuta J Michczyńska1 • Anna Pazdur \\ Radiocarbon Laboratory, Institute of Physics, Silesian University of Technology, Krzywoustego 2, 44-100 Gliwice, Poland.
}

ABSTRACT. We report on a statistical analysis of a large set of radiocarbon dates for reconstruction of paleoclimate. Probability density functions were constructed by summing the probability distributions of individual ${ }^{14} \mathrm{C}$ dates. Our analysis was based on 2 assumptions: 1) The amount of organic matter in sediments depends on paleogeographical conditions; 2) The number of ${ }^{14} \mathrm{C}$-dated samples is proportional to the amount of organic matter deposited in sediments in the examined time intervals. We quantified how many dates are required to give statistically reliable results. As an example, 785 peat dates from Poland were selected. The dates encompassed the Holocene and Late Glacial period. All dates came from the Gliwice Radiocarbon Laboratory. Results were compared with other paleoenvironmental records. Detailed analysis of the frequency distributions showed that preferential sampling plays an important part in the shape determination. The general rule to take samples from locations where visible changes of sedimentation are apparent (e.g. from the top and the bottom of the peat layer) results in narrow peaks in the probability density function near the limits of the Holocene subdivision.

\section{INTRODUCTION}

Since the 1970s, analyses of frequency distributions of radiocarbon-dated samples over restricted timescales have been carried out for several selected geographic regions. Geyh and Streif (1970) used $330{ }^{14} \mathrm{C}$ dates of sediments from lagoons and tidal flats in the Netherlands, Niedersachsen, and Schleswig-Holstein to investigate sea-level variations on a regional scale. The basic assumption of their study was that ${ }^{14} \mathrm{C}$ dates could be expected only for periods in which intensive peat formation occurred. In 1980, Geyh presented a Holocene North Sea sea-level history based on a set of $641{ }^{14} \mathrm{C}$ dates. In the same article, the limitations of the statistical evaluation of ${ }^{14} \mathrm{C}$ dates using histograms were discussed. Pazdur and Pazdur (1986b) analyzed the frequency distribution of ${ }^{14} \mathrm{C}$ dates between arbitrarily chosen limits of 10 and $15 \mathrm{kyr}$ BP. They used all the ${ }^{14} \mathrm{C}$ dates made before 1985 in the Gliwice Radiocarbon Laboratory for the territory of Poland to construction a cumulative histogram. The authors found prominent maxima corresponding to the interstadials of Bölling and Alleröd, and the minima of the Older and Younger Dryas. Also, the beginning of the Holocene was marked by a sharp increase in the frequency of ${ }^{14} \mathrm{C}$ dates. In turn, Goździk and Pazdur (1987) analyzed the frequency of ${ }^{14} \mathrm{C}$ dates from the territory of Poland in the time interval from 12 to $45 \mathrm{kyr} \mathrm{BP}$ based on a set of 193 samples. Although, in the authors' opinion, a significantly larger set of ${ }^{14} \mathrm{C}$ dates was necessary to draw detailed conclusions, the frequency distribution revealed good agreement with conclusions drawn from geological, paleobotanical, and geomorphological evidence and they suggested the dates would be useful in reconstruction of paleoclimate. Pazdur et al. (1995) presented the age distribution of speleothems from the Kraków-Wielun Upland, southern Poland. The principal period of speleothem deposition fell within the Holocene; in particular, the maximum peak of the probability density approximately fitted the climatic optimum of the Holocene (i.e. Atlantic period). The older dates ranged from 48 to $20 \mathrm{kyr}$. These boundaries coincided almost exactly with the Interplenivistulian climatostratigraphic unit. ${ }^{14} \mathrm{C}$ dating, which was primarily used simply to determine the age of sediment-containing samples, became an important source of information on the development of some geologic processes in the past. It should be stressed that the analysis of the frequency distribution of results from other dating methods has also been used in paleoclimate study.

${ }^{1}$ Corresponding author. Email: djm@radiocarbon.gliwice.pl.

(C) 2004 by the Arizona Board of Regents on behalf of the University of Arizona Proceedings of the 18th International Radiocarbon Conference, edited by N Beavan Athfield and R J Sparks RADIOCARBON, Vol 46, Nr 2, 2004, p 733-744 
Hercman (2000) presented an attempt to utilize the U/Th dates of speleothems as a source of paleoclimatic data. She also presented a detailed review of earlier studies concerning the analysis of growth frequency curves of cave speleothems. The speleothem deposition intensity is influenced by the changing climate, which is reflected in a clustering of dating results in certain time intervals. An example of a frequency distribution of 456 results of TL dating of loess samples was discussed by Singhvi et al. (2001) and Bluszcz and Michczyński (1999).

We report on a statistical analysis of a large set of ${ }^{14} \mathrm{C}$ dates for the reconstruction of the paleoenvironment. Our analysis was based on 2 assumptions:

1. The amount of organic matter in sediments depends on paleogeographical conditions.

2. The number of ${ }^{14} \mathrm{C}$-dated samples is proportional to the amount of organic matter deposited in sediments in studied time intervals.

When the criteria for including ${ }^{14} \mathrm{C}$ dates in an analyzed set are chosen suitably (Geyh 1980; Goździk and Pazdur 1987; Stolk et al. 1994), fluctuations in the constructed cumulative distribution reflect changes of the investigated geologic phenomenon. The cumulative probability density function (CPDF) is created by superposition of individual Gaussian distributions for each ${ }^{14} \mathrm{C}$ date. Analysis of the shape of the CPDF may allow periods with favorable conditions for sedimentation (peaks of CPDF) or unfavorable conditions (gaps of CPDF) to be determined. But the key question is whether peaks and gaps are the result of environmental changes in the past or statistical and sampling fluctuations. In other words: How does one test accurately if the analyzed CPDF is significantly different from the uniform CPDF? How many dates are required to give reliable results? Geyh discussed such problems for histograms (Geyh 1980) and distinguished 3 kinds of histograms according to the value of the parameter $s$ describing statistical fluctuations:

- Reliable histograms, $s \leq 20 \%$

- Common histograms, $50 \%<s<20 \%$

- Unreliable histograms, $s \geq 50 \%$

In his article, the studied time interval is divided in a number of classes. The number of dates belonging to a certain class $l$ is a random variable. If the number of ${ }^{14} \mathrm{C}$ dates in the studied time interval is large, then this variable can be described by Poisson statistics. In such situations, the statistical fluctuation $s$, which can be expressed as the ratio of the expected value and dispersion, is easy to calculate.

\section{METHODS}

In the case of CPDFs, the situation is a little more complicated. To estimate the range of statistical fluctuation for CPDFs, we carried out a Monte Carlo experiment for different values $(N)$ of the number of ${ }^{14} \mathrm{C}$ dates in the sets $(N=50,100,200,500,1000$, and 2000), and for different values of the mean uncertainties $\Delta T=50,70,100,120,150$, and $200 \mathrm{yr}$. We assumed that the $N{ }^{14} \mathrm{C}$ dates are uniformly distributed in the time range of $0-14$ kyr. For simplification, we assumed that all dates have the same uncertainty. Using the Monte Carlo method, we generated 10,000 CPDFs for each pair of $N$ and $\Delta T$ values. On the basis of the 10,000 CPDFs, we estimated the fluctuation range as $95 \%$ confidence intervals. The results obtained for $\Delta T=120 \mathrm{yr}$ and different $N$ values and for $N=500$ dates and different uncertainty values are presented in Figure 1. To compare our results with evaluations for histograms, the parameter $s_{f}$, which describes statistical fluctuations, was calculated. The results are presented in Figure 2. In comparison with histograms, CPDF is characterized by lower statistical fluctuations, e.g., we need 1530 dates with a mean uncertainty of $115 \mathrm{yr}$ for the time range $0-14 \mathrm{kyr}$ 
BP to give reliable (according to the criteria proposed by M Geyh) results for histograms, but we would need about 785 dates for the CPDF. The minimum number of dates for the case $\Delta T=120 \mathrm{yr}$ is equal to 125 and for $\Delta T=115 \mathrm{yr}$ is equal to 200 dates.
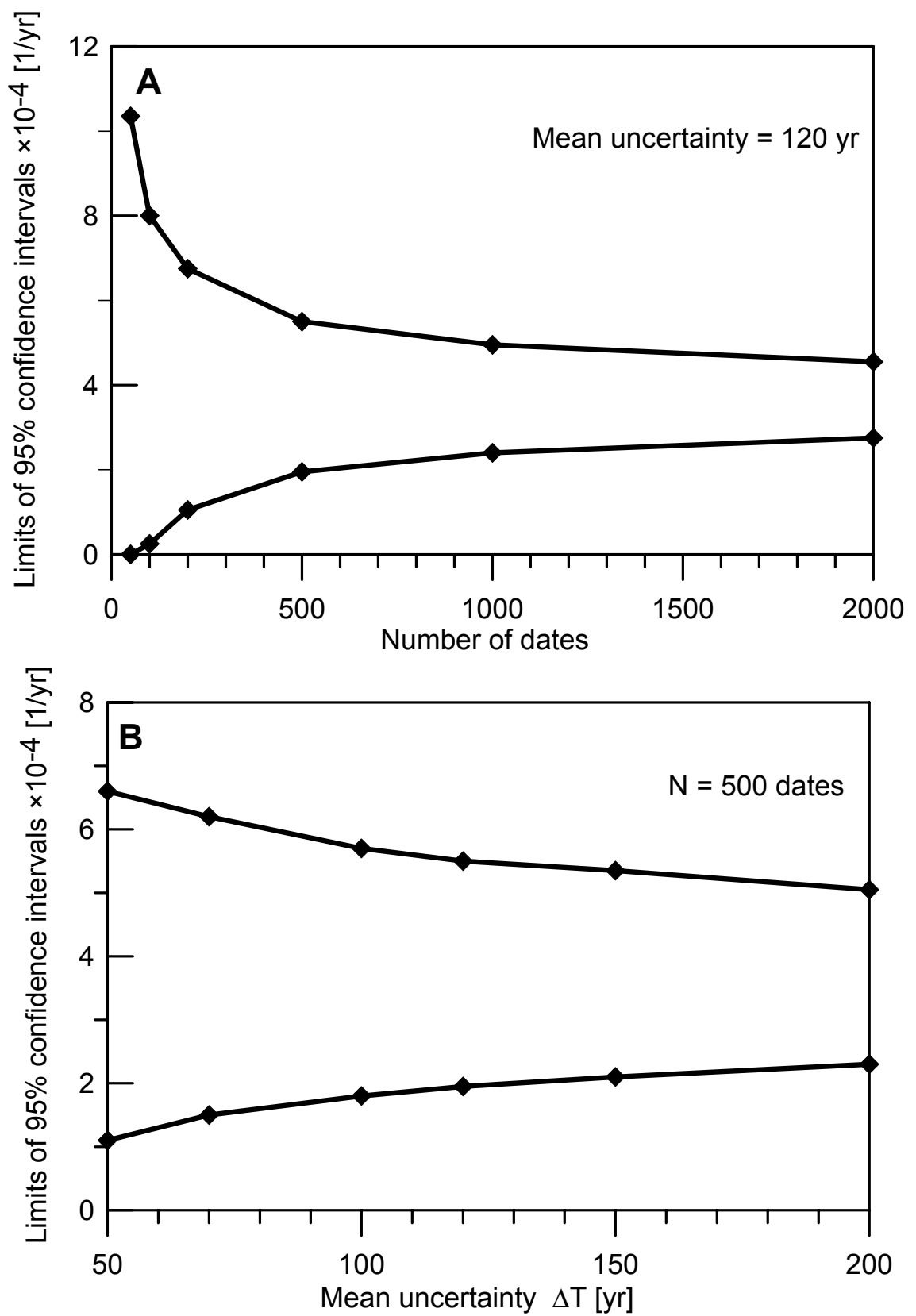

Figure 1 Values of $95 \%$ confidence intervals versus number of dates (a) and value of mean uncertainty (b). Part A shows the results for the number of dates $N=50,100,200,500,1000$, and 2000, assumed mean uncertainty 120 yr. Part B presents the results for a set of $500{ }^{14} \mathrm{C}$ dates and different values of the mean uncertainty $\Delta T=50,70,100,120,150$, and $200 \mathrm{yr}$. 

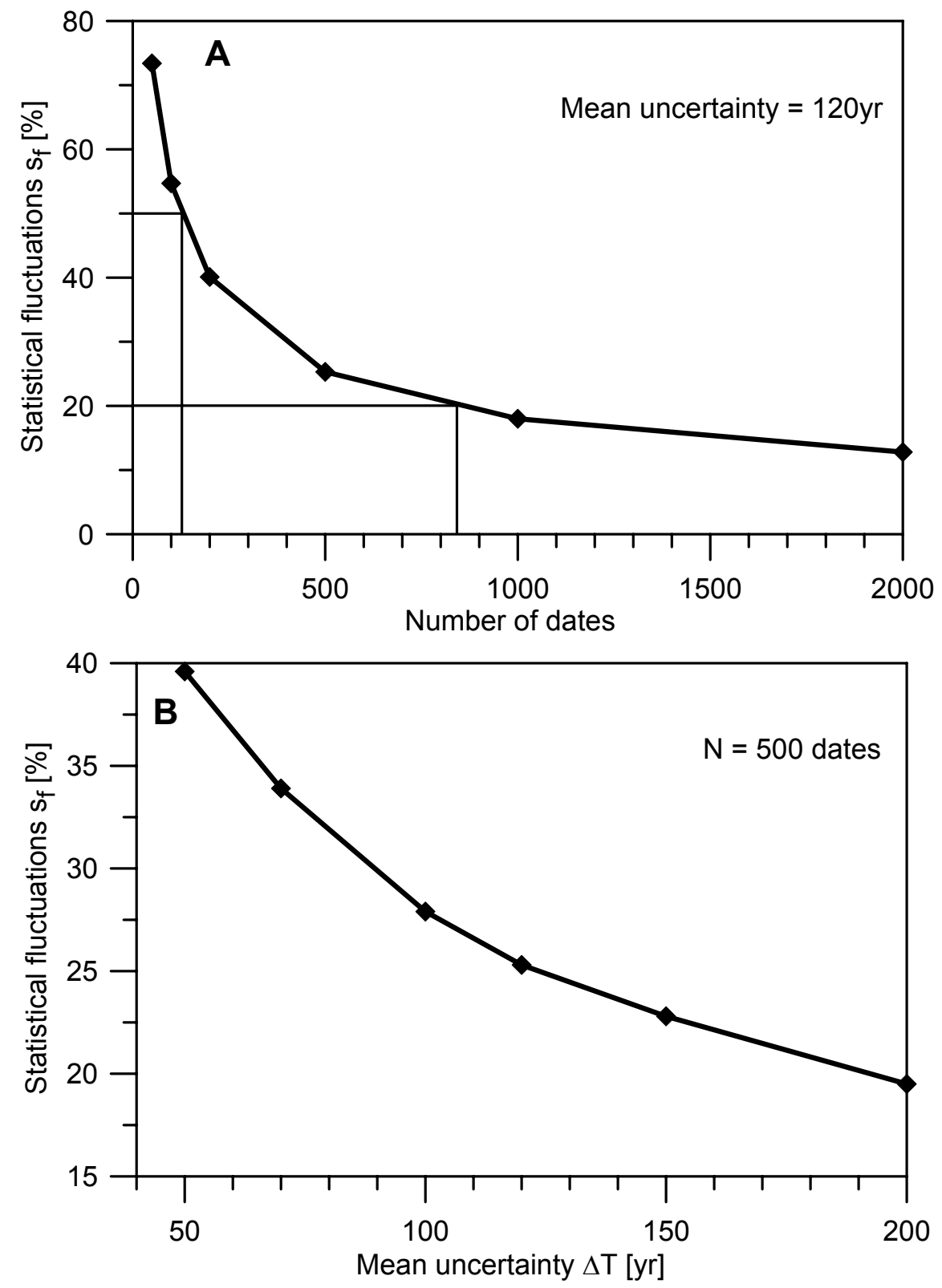

Figure 2 Statistical fluctuations $s_{f}$ value versus number of dates (a) and mean uncertainty value (b)

In order to estimate the minimum number of dates needed for construction of a reliable CPDF, we did the following:

1. Created a set of $1000{ }^{14} \mathrm{C}$ dates (using a random number generator) and calculated the appropriate CPDF;

2. Randomly sampled $N_{i}$ dates from the set of 1000 dates;

3. Calculated $C P D F_{i}$ for the selected $N_{i}$ dates; 
4. Calculated the sum of squared deviation between the original (constructed for 1000 dates) CPDF and the secondary (constructed for $N_{i}$ dates) $C P D F_{i}$;

5. Repeated steps $2-4$ one hundred times and calculated the mean sum of squared deviations MSSD;

6. Repeated steps $2-6$ for $N_{i}=50,100,150, \ldots 950$ dates.

The relationship between the mean sum of squared differences and number of dates is shown in Figure 3. We carried out the experiment for the case mean $\Delta T=115$ yr. Faster changes of MSSD are characteristic for lower $N_{i}$ values. The larger the number of dates, the smaller the MSSD value. On the basis of this simulation, we chose $N_{i}=200$ as the minimum number of dates needed for the construction of a reliable CPDF. Hercman (2000) described a similar experiment for the set of ${ }^{230} \mathrm{Th} /{ }^{234} \mathrm{U}$ dates. She proposed 150 as the minimum number of ${ }^{230} \mathrm{Th} /{ }^{234} \mathrm{U}$ dates for the analyzed time range $0-200 \mathrm{kyr}$.

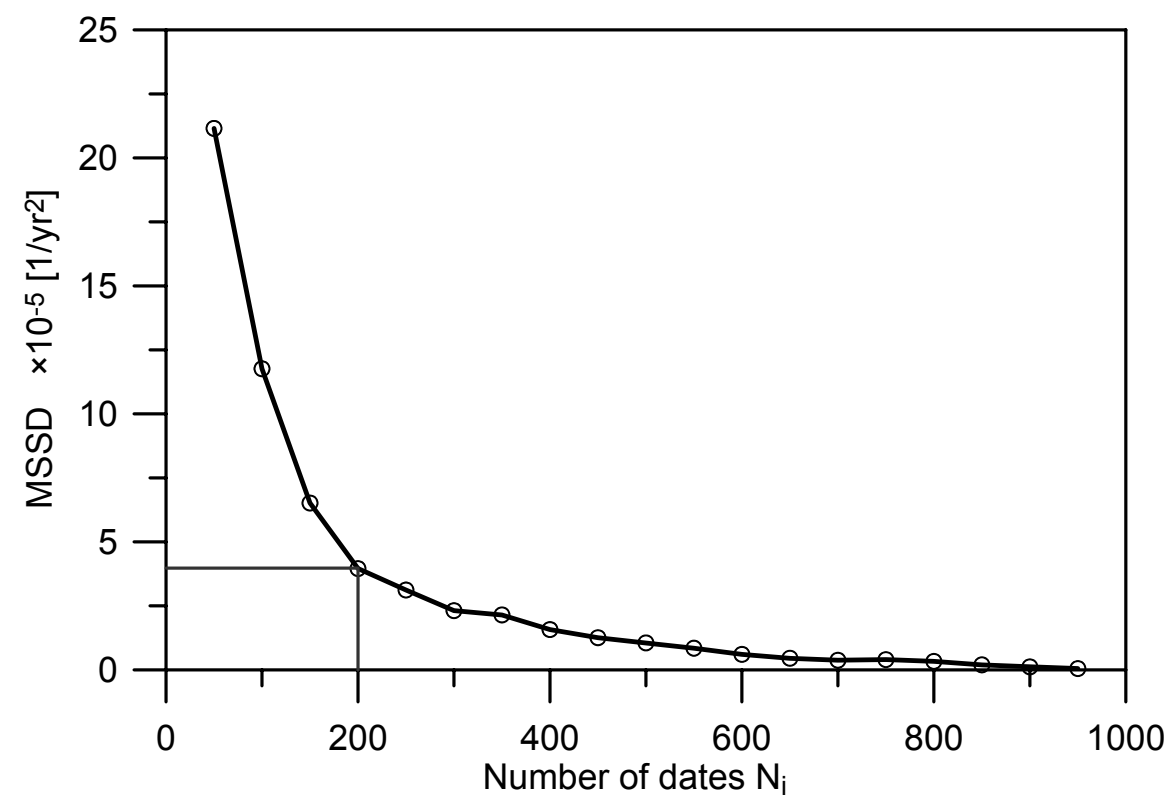

Figure 3 Results of the shape experiment $e$; Mean sum of squared deviations MSSD between the original (constructed for 1000 dates) $\mathrm{CPDF}$ and secondary (constructed for $N_{i}$ dates) $\mathrm{CPDF}_{\mathrm{i}}$.

The Monte Carlo experiment provides evidence about how the CPDF constructed for a certain set of ${ }^{14} \mathrm{C}$ dates may differ considerably from the CPDF constructed for the same number of dates but uniformly distributed on a ${ }^{14} \mathrm{C}$ timescale. The experiment gives no information about the significance of particular maxima and minima. This significance could be established by a Monte Carlo experiment using a random number generator with the same distribution as the real distribution of sedimentation of the investigated type of sample. Unfortunately, the real distribution is unknown. To estimate it, the "Bootstrap Method" (Efron and Tibishrani 1993; Hercman 2000) may be used. This method assumes only that the chosen set of dates is representative of the sediment type over the investigated time period. The scheme of the Bootstrap Method algorithm is shown in Figure 4, and illustrative $95 \%$ confidence intervals calculated for a set of 785 dates of peat from the territory of Poland (see "Analyzed Material") are shown in Figure 5. 


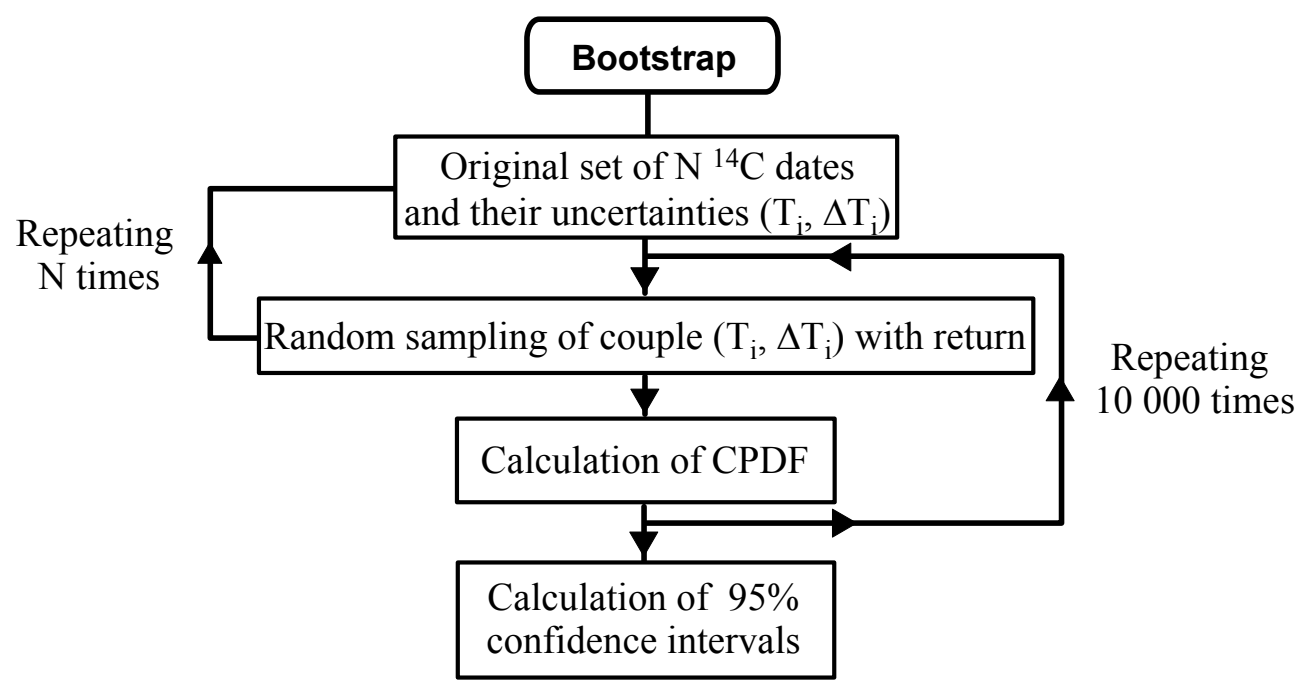

Figure 4 Scheme of the Bootstrap experiment

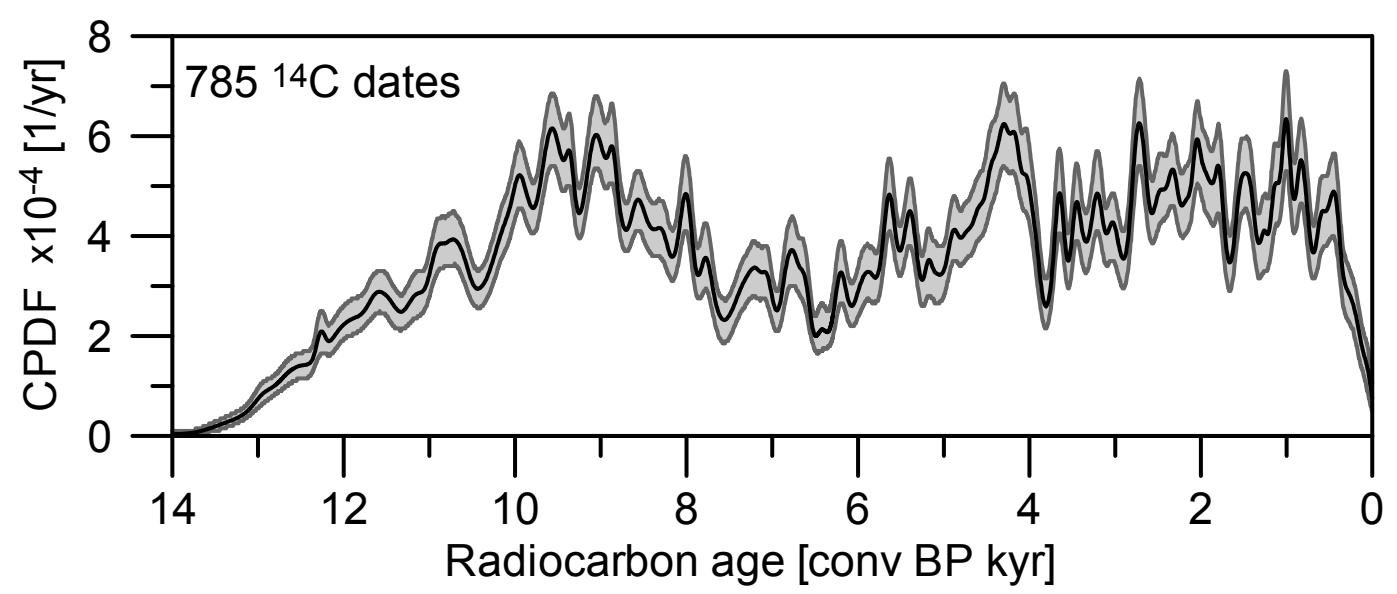

Figure 5 An example of $95 \%$ confidence intervals calculated for a set of 785 dates of peat (see "Analyzed Material") on the basis of the Bootstrap Method.

The correct interpretation of the CPDFs depends on the calendar timescale. It is especially important when comparisons with other paleoenvironmental records (e.g. varves) are made (Bartlein et al. 1995). Differences between the ${ }^{14} \mathrm{C}$ and calendar timescale can be the source of misleading impressions of synchronicity of some events or incorrect estimation of the duration of episodes if ${ }^{14} \mathrm{C}$ ages are not calibrated. In order to overcome these difficulties, the method of probabilistic calibration of ${ }^{14} \mathrm{C}$ dates was applied. We used an updated version of the Gliwice Radiocarbon Laboratory Calibration Programme GdCALIB (Pazdur and Michczyńska 1989; Michczyńska et al. 1990). The method of constructing CPDF on the calendar timescale in our program is the same as in OxCal (Bronk Ramsey 1995). We have not used any smoothing. Our earlier study (Michczyńska et al. 2003) shows that the degree of smoothing has no influence on the main peaks and gaps (cf. Figure 6). In the case when only the global changes are the subject of investigation, the degree of smoothing does not play an important role. With the aim of establishing whether the analyzed CPDFs are visibly different to 
CPDFs calculated for sets with the same number of dates but for which the dates are uniformly distributed in the calendar timescale, a Monte Carlo experiment (Experiment 2) was performed. Results of the simulations are presented in Figure 7 in the form of $95 \%$ confidence intervals for different numbers of dates in the analyzed set $(N=100,200$, and 1000). The influence of the shape of the calibration curve on the $95 \%$ confidence intervals is clearly visible.

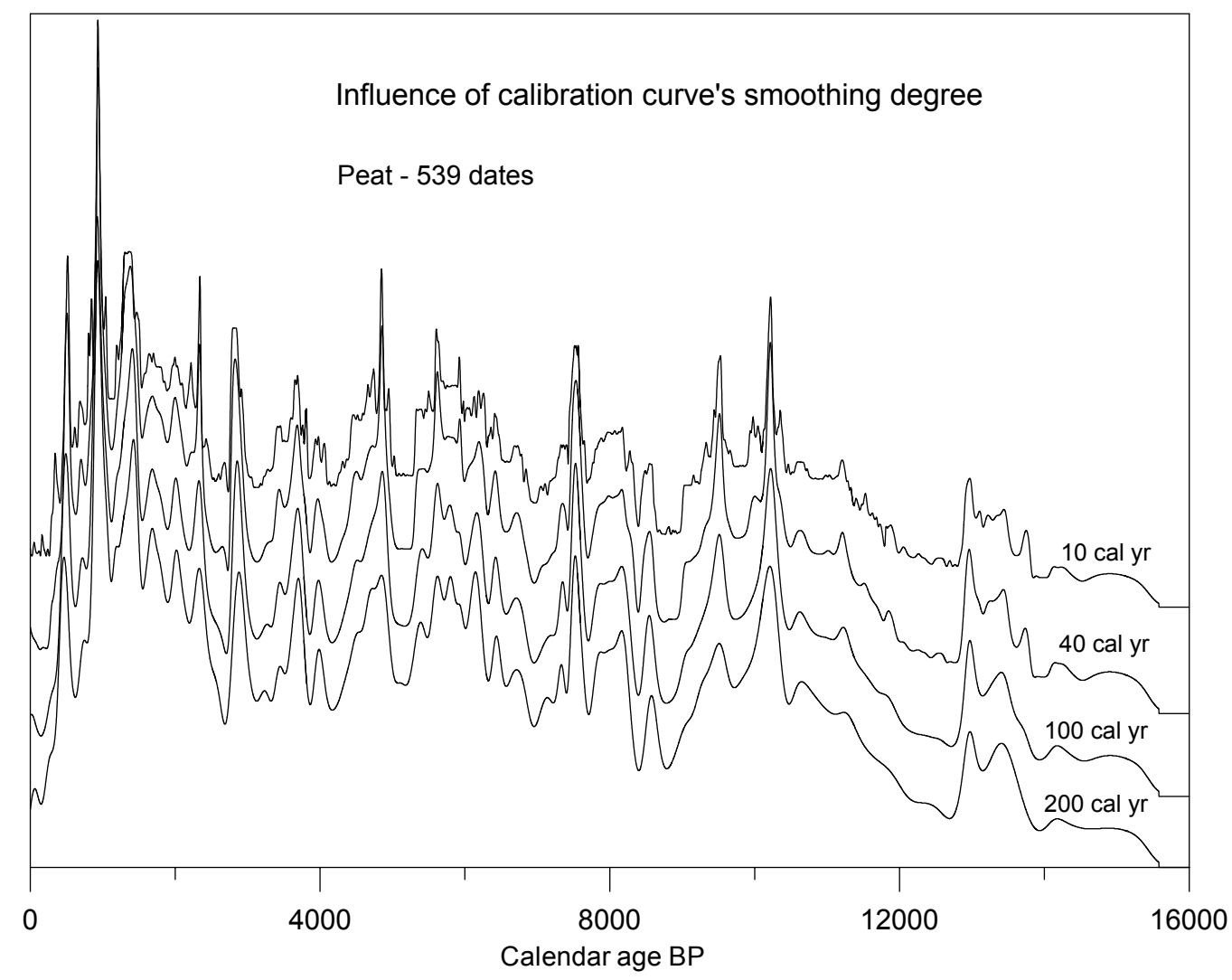

Figure 6 The influence of the calibration curve's smoothing degree on the shape of CPDF. The distributions are constructed for 539 dates of peat samples coming from the whole territory of Poland. Values of the calibration curve's smoothing degree are given in calendar yr; van der Plicht (1993) described details of the smoothing procedure. Particular graphs were vertically separated for higher clarity of the figure (according to Michczyńska et al. 2003).

\section{ANALYZED MATERIAL}

A method of statistical analysis for large sets of ${ }^{14} \mathrm{C}$ dates was described with the purpose of identifying environmental changes in the past recorded in the various types of sediment. In this paper, we present the first verification of this method on the basis of ${ }^{14} \mathrm{C}$ dates for peat from Poland. Poland lies in the temperate climate zone of the Northern Hemisphere (latitude $49-55^{\circ} \mathrm{N}$, longitude $14-24^{\circ} \mathrm{E}$ ). There are 49,620 peat bogs in Poland (Ilnicki and Żurek 1996). It could be expected that the statistical analysis will show time periods favorable and unfavorable for peat deposition.

For the statistical analysis, 785 dates of peat from Poland were selected. These dates encompassed the Holocene and Late Glacial period (last $14{ }^{14} \mathrm{C}$ kyr). The number of ${ }^{14} \mathrm{C}$ dates in particular millennial time periods are shown in Table 1. Dated samples came from Poland, except for those 


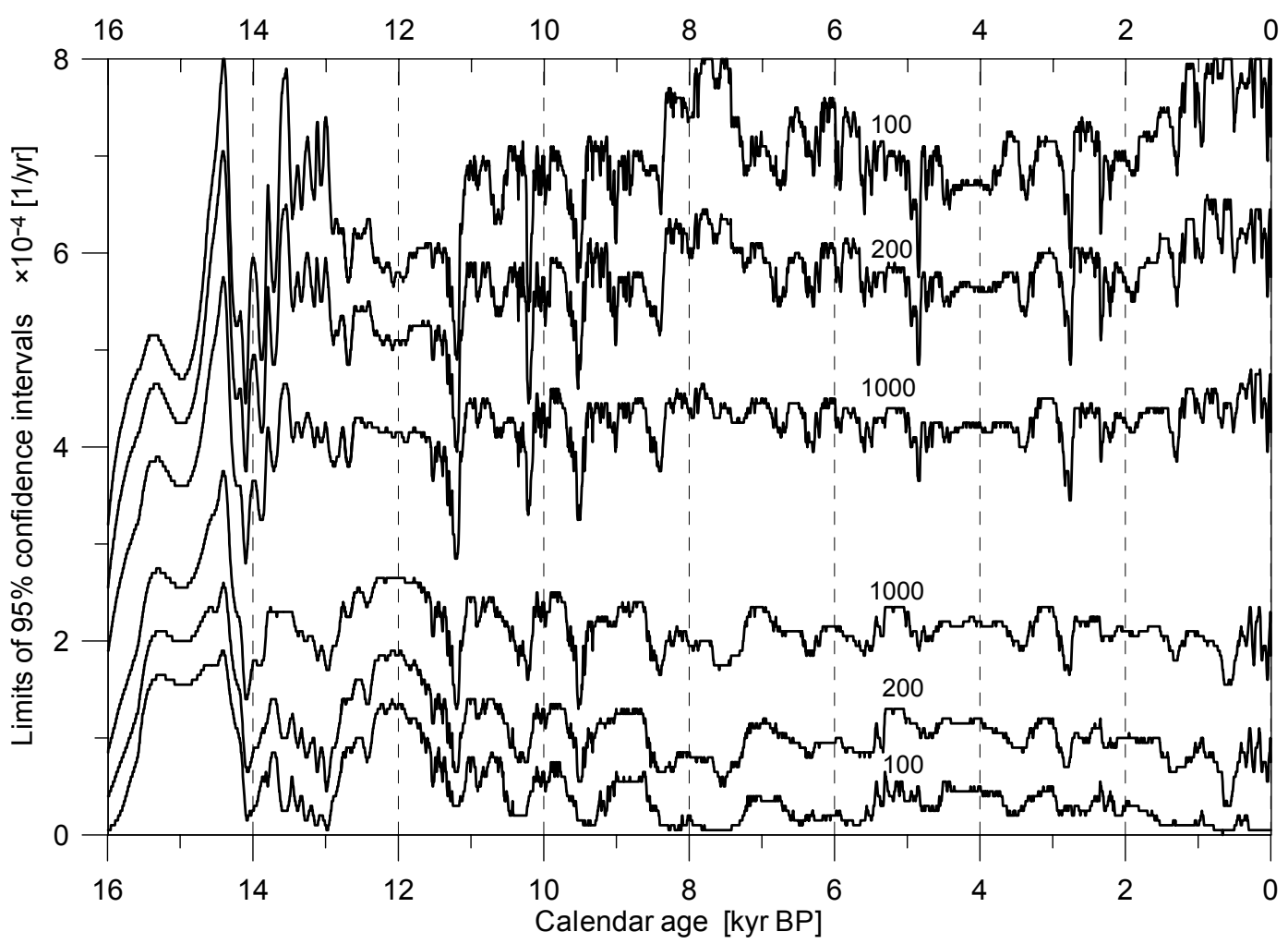

Figure 7 Results of 2nd Monte Carlo experiment. This experiment was executed for $\mathrm{N}=100,200$, and 1000. For all simulations, the mean uncertainty was $115 \mathrm{yr}$.

from part of the Baltic Coast where changes in the Baltic sink range may influence peat deposition. All dates came from the Gliwice Radiocarbon Laboratory. After pretreatment and carbonization, the samples were combusted, and $\mathrm{CO}_{2}$ was purified by the standard method used in the Gliwice Radiocarbon Laboratory (Pazdur and Pazdur 1986a). Finally, ${ }^{14} \mathrm{C}$ activity measurements were carried out by gas proportional counting (Pazdur et al. 2000). The result of ${ }^{14} \mathrm{C}$ dating is given as measured ${ }^{14} \mathrm{C}$ age $T$ and its uncertainty $\Delta T(T \pm \Delta T)$. According to the commonly accepted convention (Stuiver and Polach 1977), the $\Delta T$ value is calculated only on the basis of statistical analysis of the measurements and properties of the apparatus without taking into account any extralaboratory factors. Because peat is a typical organic material and often dated using ${ }^{14} \mathrm{C}$, this type of deposit was chosen for analysis.

\section{RESULTS AND CONCLUSIONS}

We constructed a CPDF for the 785 chosen ${ }^{14} \mathrm{C}$ dates. Results in the calendar timescale are presented in Figure 8. The values of the CPDF exceed the 95\% confidence intervals (calculated for $785{ }^{14} \mathrm{C}$ dates uniformly distributed on the calendar timescale) for $36.5 \%$ of the analyzed interval. This figure indicates that the real distribution of dates on the calendar timescale is not uniform.

For the Late Glacial/Holocene transition, there are many paleoclimatic records. Figure 9 presents an example of the comparison of the CPDF with the isotopic composition of authigenic carbonates in the Younger Dryas section of sediments from Lake Gościąż (Kuc et al. 1998), methane concentra- 
Table 1 Number of ${ }^{14} \mathrm{C}$ dates of peat samples versus millennial time periods.

\begin{tabular}{cc}
\hline Time range conventional BP & $\mathrm{Nr}$ of ${ }^{14} \mathrm{C}$ dates \\
\hline $0-1000$ & 60 \\
$1000-2000$ & 72 \\
$2000-3000$ & 76 \\
$3000-4000$ & 62 \\
$4000-5000$ & 80 \\
$5000-6000$ & 56 \\
$6000-7000$ & 40 \\
$7000-8000$ & 49 \\
$8000-9000$ & 70 \\
$9000-10,000$ & 83 \\
$10,000-11,000$ & 58 \\
$11,000-12,000$ & 40 \\
$12,000-13,000$ & 22 \\
$13,000-14,000$ & 5 \\
\hline
\end{tabular}

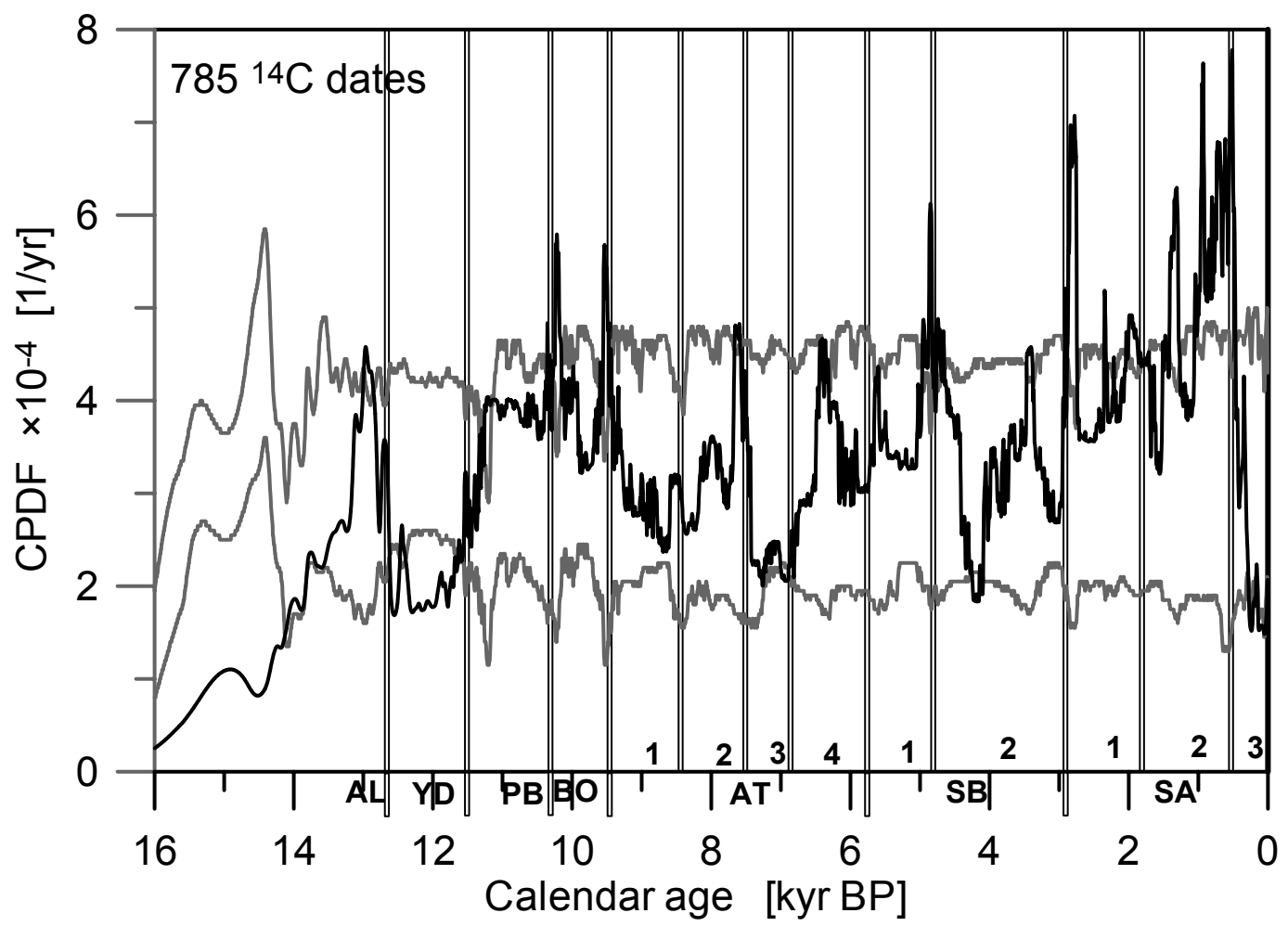

Figure 8 Cumulative probability density function (CPDF) for $785{ }^{14} \mathrm{C}$ dates from the interior of Poland is presented as the black curve. The $95 \%$ confidence interval is marked in grey based on the uniform distribution on the calendar timescale (cf. experiment Monte Carlo 2). Vertical lines indicate borders of the subdivision of the Late Glacial and Holocene period (Starkel 1999; after calculation on the calendar timescale).

tions in the GRIP ice core (Blunier et al. 1995), and $\delta^{18} \mathrm{O}$ composition in the same ice core (Johnsen et al. 1997). Excellent agreement of the shape of CPDF and other environmental records for Late Glacial/Holocene transition testify the validity of basic assumptions of the statistical analysis. We 


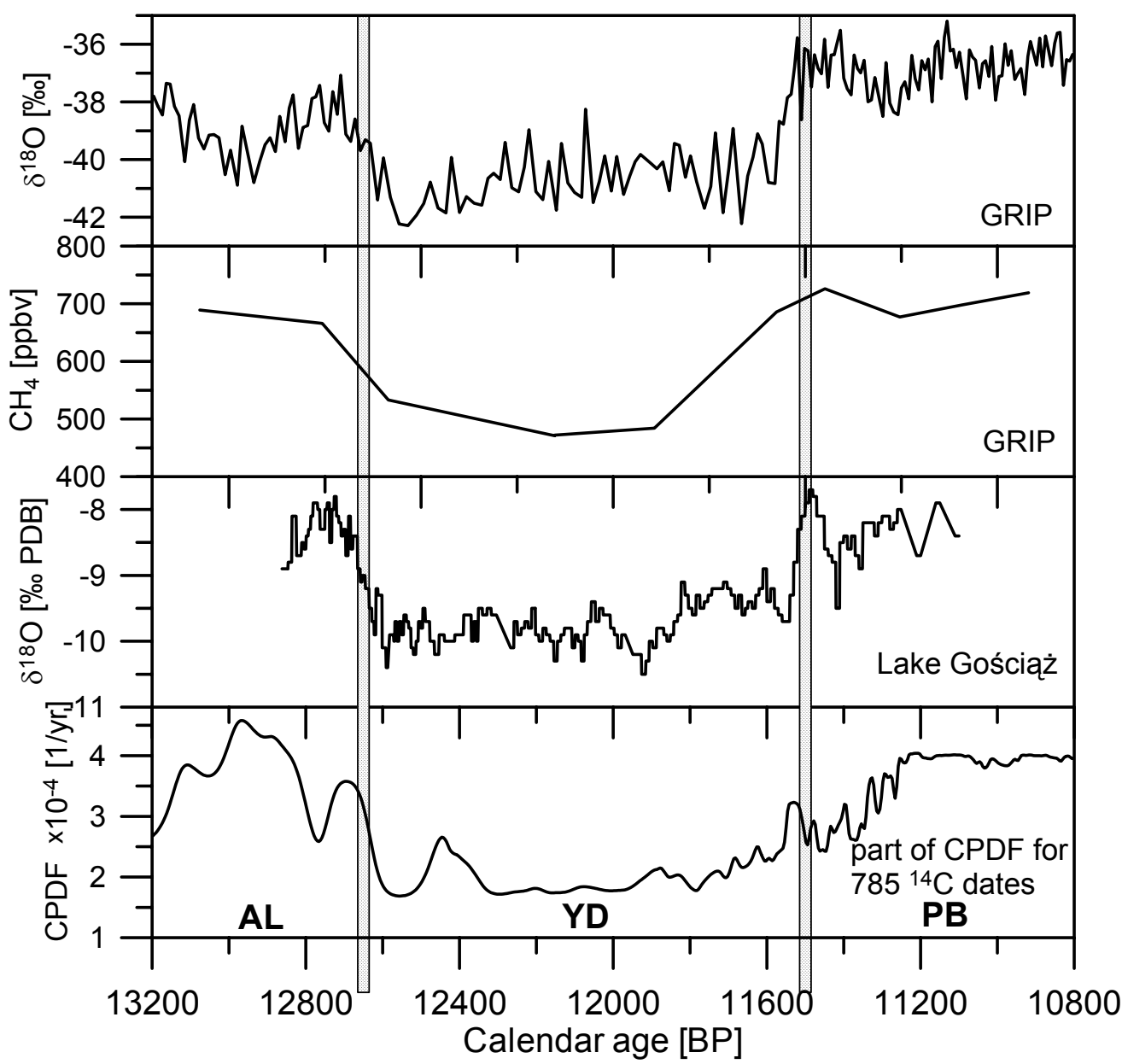

Figure 9 Comparison of part (10,800-13,200 cal BP) of the CPDF constructed for 785 dates and isotopic composition of authigenic carbonates in the Younger Dryas section of the sediments from Lake Gościąż (Kuc et al. 1998), $\delta^{18} \mathrm{O}$ in the Greenland ice core (Johnsen et al. 1997), and methane concentration in the Greenland ice core (Blunier et al. 1995). Vertical grey lines indicate transition AL/YD and YD/PB established in studies of Lake Gościąż sediments (Goslar 1998).

have assumed that the random character of dates is preserved in the case of a large set of ${ }^{14} \mathrm{C}$ dates. Dates came from a large territory, and different investigators interested in various scientific disciplines collected them. However, the shape of the CPDF constructed for the 785 dates is strange. We observed narrow peaks; such narrow peaks are characteristic only for the real CPDF. They are absent for the CPDFs generated in Monte Carlo experiments. We could expect essential changes in the shape of CPDFs at those time periods where changes in environment were present, but the narrow peaks are unexpected. We suppose that their presence near the border of the Holocene subdivisions (cf. Figure 8; Starkel 1999, after calculation on calendar timescale) may be the result of the sampling methodology. Samples for ${ }^{14} \mathrm{C}$ dating are frequently collected only from selected horizons which are of special interest from the point of view of investigator. Because of economic reasons, only a limited number of organic layers can be dated. The general rule of taking samples from places of visible sedimentation changes (e.g. from the top and bottom of the peat layer) may be the reason that samples from the border of the Holocene subdivisions are collected essentially frequently. On 
the one hand, preferential sampling hampers analysis, but on other hand, it may be useful to establish the border of the Holocene subdivision on the calendar scale for the analyzed geographical area.

The authors intend to repeat the research, basing it only on ${ }^{14} \mathrm{C}$ dates received for peat samples coming from raised bogs. These type of peat bogs supply all of the moisture from the atmosphere; therefore, the humidity in the upper peat layers depends essentially on precipitation, temperature, and evaporation.

We made the following conclusions from our analysis:

- 200 is the minimum number of dates required for the time interval 0-14 kyr;

- The first Monte Carlo experiment showed that CPDFs have lower statistical fluctuations than histograms;

- The first Monte Carlo experiment showed that the CPDF for 785 dates with a mean uncertainty of $115 \mathrm{yr}$ in the range of $0-14 \mathrm{kyr}$ BP is reliable according to the criteria proposed by Geyh (1980); for histograms, 1530 dates from the same time interval would be required;

- Calculated 95\% confidence intervals in Monte Carlo Experiments 1 and 2 allow us to state that the CPDF constructed for the real $785{ }^{14} \mathrm{C}$ peat dates from Poland are visibly different than the curve constructed for dates uniformly distributed on the ${ }^{14} \mathrm{C}$ timescale and on the calendar timescale;

- Excellent shape agreement of the CPDF with other environmental records for the Late Glacial/ Holocene transition indicate the validity of the basic assumptions of the statistical analysis;

- Along with the assumed proportionality between the number of ${ }^{14} \mathrm{C}$ dates and the amount of deposited organic matter in the studied time intervals, the influence of preferential sampling is visible. The general rule to take samples for ${ }^{14} \mathrm{C}$ dating where changes in sedimentation are observed or from a point in the profile where important changes in pollen are apparent, results in narrow peaks in the CPDF near the climatostratigraphic subdivision.

\section{ACKNOWLEDGEMENTS}

This study was supported by the Polish Committee for Scientific Research through the grant nr 3 PO4E 05524.

\section{REFERENCES}

Bartlein PJ, Edwards ME, Shafer SL, Barker ED. 1995. Calibration of radiocarbon ages and the interpretation of paleoenvironmental records. Quaternary Research 44:417-24.

Blunier T, Chappellaz JA, Schwander J, Stauffer B, Raynaud D. 1995. Variations in atmospheric methane concentration during the Holocene epoch. Nature 374: 46-9.

Bluszcz A, Michczyński A. 1999. Statistical methods in chronostratigraphy. In: Pazdur A, editor. Geochronology of Upper Quaternary in Poland. Wojewoda: Wind J. p 71-9. In Polish.

Bronk Ramsey C. 1995. Radiocarbon calibration and analysis of stratigraphy: the OxCal program. Radiocarbon 37(2):425-30.

Efron B, Tibshirani RJ. 1993. An Introduction to the Bootstrap. New York: Chapman and Hall. 436 p.

Geyh MA. 1980. Holocene sea-level history: case study of the statistical evaluation of ${ }^{14} \mathrm{C}$ dates. Radiocarbon 22(3):695-704.

Geyh MA, Streif H. 1970. Studies on coastal movements and sea-level changes by means of the statistical evaluation of ${ }^{14} \mathrm{C}$-data. Proceedings of the "Symposium on Coastal Geodesy." Münich, 20-24 July 1970. p 599611.

Goslar T, Arnold M, Pazdur MF. 1998. Variations of atmospheric ${ }^{14} \mathrm{C}$ concentrations at the Pleistocene/ Holocene transition, reconstructed from the Lake Gościąż sediment. In: Ralska-Jasiewiczowa M, Goslar T, Madeyska T, Starkel L, editors. Lake Gościąż, Central Poland. A Monographic Study. p 162-71.

Goździk J, Pazdur MF. 1987. Frequency distribution of ${ }^{14} \mathrm{C}$ dates from Poland in the time interval $12-45 \mathrm{kyr}$ BP and its palaeogeographical implications. Zeszyty Naukowe Politechniki Ślaskiej, s. MatematykaFizyka, z. 56, Geochronometria 4:27-42. 
Hercman H. 2000. Reconstruction of paleoclimatic changes in Central Europe between 10 and 200 thousand years BP, based on analysis of growth frequency of speleothems. Studia Quaternaria 17:35-70.

Ilnicki P, Żurek S. 1996. Peat resources in Poland. In: Lappalainen E, editor. Global Peat Resources. Jyväskylä: International Peat Society, Geological Survey of Finland. p 119-25.

Johnsen SJ, Clausen HB, Dansgaard W, Gundestrup NS, Hammer CU, Andersen U, Andersen KK, Hvidberg CS, Dahl-Jensen D, Steffensen JP, Shoji H, Sveinbjörnsdóttir AE, White JWC, Jouzel J, Fisher D. 1997. The $\delta^{18} \mathrm{O}$ record along the Greenland Ice Core Project deep ice core and the problem of possible Eemian climatic instability. Journal of Geophysical Research 102:26,397-410.

Kuc T, Różański K, Duliński M. 1998. Isotopic indicators of the Late Glacial/Holocene transition recorded in the sediments of Lake Gościąż. In: Ralska-Jasiewiczowa M, Goslar T, Madeyska T, Starkel L, editors. Lake Gościaż, Central Poland. A Monographic Study. p 158-62.

Michczyńska DJ, Michczyńsky A, Pazdur A, Żurek S. 2003. ${ }^{14} \mathrm{C}$ dates of peat for reconstruction of environmental changes in the past. Geochronometria 22:4754.

Michczyńska DJ, Pazdur MF, Walanus A. 1990. Bayesian approach to probabilistic calibration of radiocarbon ages. In: Mook WG, Waterbolk HT, editors. Proceedings of the 2nd International Symposium ${ }^{14} \mathrm{C}$ and Archaeology. Strasburg. PACT 29:69-79.

Pazdur A, Michczyński A, Pawlyta J, Spahiu P. 2000. Comparison of the radiocarbon dating methods used in the Gliwice Radiocarbon Laboratory. Geochronometria 18:9-14.

Pazdur A, Pazdur MF. 1986a. Aparatura pomiarowa Laboratorium ${ }^{14} \mathrm{C}$ w Gliwicach. Doświadczenia konstrukcyjne i eksploatacyjne (The measuring equipment of the Gliwice Radiocarbon Laboratory. Experience gathered in the construction and exploitation). Zeszyty Naukowe Politechniki Ślaskiej, seria MatematykaFizyka, z.46, Geochronometria 1:55-69.

Pazdur A, Pazdur MF. 1986b. Radiocarbon chronology of the Late Glacial period in Poland. Acta Interdisciplinaria Archaeology 4:61-71.

Pazdur A, Pazdur MF, Pawlyta J, Górny A, Olszewski M. 1995. Paleoclimatic implications of radiocarbon dating of speleothems from Cracow-Wieluń Upland, S Poland. Radiocarbon 37(2):103-10.

Pazdur MF, Michczyńska DJ. 1989. Improvement of the procedure for probabilistic calibration of radiocarbon dates. In: Long A, Kra RS, Srdoć D, editors. Proceedings of the 13 th International ${ }^{14} \mathrm{C}$ Conference. Radiocarbon 31(3):824-32.

Singhvi AK, Bluszcz A, Bateman MD, Someshwar Rao M. 2001. Luminescence dating of loess-paleosol sequences and coversands: methodological aspects and paleoclimatic implications. Earth Science Reviews 54: 193-211.

Stolk A, Törnqvist TE, Hekhuis KPV, Berendsen HJA, van der Plicht J. 1994. Calibration of ${ }^{14} \mathrm{C}$ histograms: a comparison of methods. Radiocarbon 36(1):1-10.

Stuiver M, Polach HA. 1977. Discussion: reporting of ${ }^{14} \mathrm{C}$ data. Radiocarbon 19(3):355-63.

van der Plicht J. 1993. The Groningen radiocarbon calibration program. Radiocarbon 35(1):231-7. 